\title{
Characterization of a plasmid from moderately halophilic eubacteria
}

\author{
Rosario Fernandez-Castillo, Carmen Vargas, Joaquin J. Nieto, ${ }^{*}$ Antonio Ventosa and \\ FRANCISCO RUIZ-BERRAQUERO
}

Department of Microbiology, Faculty of Pharmacy, University of Sevilla, Sevilla 41012, Spain

(Received 28 October 1991; revised 30 January 1992; accepted 18 February 1992)

\begin{abstract}
A plasmid has been isolated for the first time from moderately halophilic eubacteria. Halomonas elongata, Halomonas halmophila, Deleya halophila and Vibrio costicola were found to harbour an $11.5 \mathrm{kbp}$ plasmid (pMH1). The plasmid was isolated and characterized after transformation into Escherichia coli JM101 cells. A restriction map was constructed, and unique restriction sites for EcoRI, EcoRV and ClaI were detected. The occurrence of such a plasmid in the original halophilic strains was confirmed by Southern hybridization. The plasmid carries genetic determinants that mediate resistance to kanamycin, tetracycline, and neomycin. This property, together with its relatively small size, its stability in $E$. coli cells, and the presence of unique restriction sites, makes pMH1 a good candidate for the development of a cloning vector for moderate halophiles.
\end{abstract}

\section{Introduction}

Besides the extremely halophilic archaeobacteria, the moderate halophiles are the most important group of micro-organisms adapted to live in hypersaline habitats, and are defined as those micro-organisms which grow optimally in media containing 0.5 to $2.5 \mathrm{M}$-salt (Kushner, 1978). Despite extensive studies on their taxonomy, physiology, and ecology (Ventosa, 1988; Kushner \& Kamekura, 1988; Rodriguez-Valera, 1986; RodriguezValera et al., 1985), the study of their genetics is still in its infancy. Little information is available on the occurrence of genetic exchange mechanisms in these halophiles, or on the isolation of stable mutants or autochthonous plasmids which could be used as cloning vectors, all of which are required for the development of molecular biology studies. The aim of the present study was to isolate plasmids which could be used as cloning vectors in further genetic studies of moderately halophilic strains. In this paper, we report the isolation and characterization of a plasmid, pMH1, present in four moderate halophiles, which displays suitable genetic features for use as a cloning vector. To our knowledge, this is the first plasmid described for moderately halophilic eubacteria, as well as the first demonstration of DNA transfer from moderately halophilic to nonhalophilic bacteria.

- Author for correspondence. Tel. 5 4556765; fax 54628162.

\section{Methods}

Bacterial strains. The moderate halophiles used in the majority of experiments were Halomonas elongata ATCC 33173, Halomonas halmophila ATCC 19717, Deleya halophila CCM 3662 and Vibrio costicola NCMB 701. Another 32 moderately halophilic strains belonging to the genera Marinococcus, Salinicoccus, Volcaniella and Vibrio were also used when screening for the presence of plasmids, and for hybridization experiments, the extremely halophilic archaeobacteria Halobacterium salinarum NRC 34002, Haloferax gibbonsii ATCC 33500 and Haloferax volcanii NCMB 2012. Furthermore, Escherichia coli strain JM109 (Yanisch-Perron et al., 1985), which carried no detectable antibiotic resistance, was used as host for transformation procedures, conjugations and plasmid DNA preparations.

Growth conditions. All moderate halophiles were grown in a saline medium (SWYE) containing $10 \%(\mathrm{w} / \mathrm{v})$ total salts (Nieto et al., 1989) to which $0.5 \%$ yeast extract (Difco) was added. The extremely halophilic strains were grown in a similar medium but with $25 \%(\mathrm{w} / \mathrm{v})$ total salts. $E$. coli was grown in Luria medium (LB) (Maniatis et al., 1982). When needed, all media were solidified with $2 \%(w / v)$ Bacto-agar (Difco). Antibiotics were added when required as either filter-sterilized concentrate in water or ethanol $(70 \%)$. All cultures were incubated at $37^{\circ} \mathrm{C}$.

DNA isolation. Routine small-scale isolation of plasmid DNA from $E$. coli was performed by the alkaline lysis method as described by Morelle (1989). Large amounts of plasmid DNA were obtained by $\mathrm{CsCl} /$ ethidium bromide density gradient ultracentrifugation at $142000 \mathrm{~g}$ for $36 \mathrm{~h}$ in a Sorvall AH-650 rotor. Genomic DNA was isolated according to Ausubel et al. (1989).

Transformation and screening for antibiotic resistance. Plasmid DNA obtained from $10 \mathrm{ml}$ of culture was resuspended in $50 \mu 1$ TE buffer $(10 \mathrm{mM}$-Tris/HCl/1 mM-EDTA, pH 8) and used to transform $200 \mu \mathrm{l}$ of competent E. coli JM101 cells. Preparation of competent cells and 
transformation were performed according to Maniatis et al. (1982). To screen for plasmid-associated antibiotic resistance phenotypes, transformed cells of $E$. coli were tested for resistance to a range of antibiotics. Antibiotics were added to these final concentrations $\left(\mu \mathrm{g} \mathrm{ml}^{-1}\right)$ : ampicillin, 50; chloramphenicol, 125; erythromycin, 80; gentamycin, 50; kanamycin, 20; nalidixic acid, 30; neomycin, 30; spectinomycin, 80; streptomycin, 500; and tetracycline, 20 (Maniatis et al., 1982). Parallel controls of the competent cells were also carried out to detect spontaneous resistant mutants.

Restriction endonuclease digestion and gel electrophoresis. Plasmid and chromosomal DNA were digested as recommended by the enzyme manufacturer (Boehringer). Digested DNA was separated by horizontal electrophoresis on $0.8 \%$ agarose gels (Sigma) in Tris/borate/EDTA buffer, pH 8.3. For physical mapping of the plasmid, the agarose concentration was either increased or decreased in order to detect smaller or larger DNA fragments, respectively. Gels were stained with ethidium bromide (Sigma) $\left(5 \mu \mathrm{g} \mathrm{ml}^{-1}\right.$ for $\left.10 \mathrm{~min}\right)$, destained in water, and photographed under $254 \mathrm{~nm}$ ultraviolet light. The molecular masses of the plasmid fragments were estimated by comparison with HindIII-digested bacteriophage lambda DNA fragments.

DNA hybridization. Plasmid and genomic DNA were digested with restriction endonucleases, fractionated by agarose gel electrophoresis, and transferred to nylon filters (Amersham) as described by Southern (1975). $\left[\alpha-{ }^{32}\right.$ P]dCTP-labelled DNA was prepared by the multiprime DNA-labelling system (Amersham). Specific activities of $10^{7}-10^{8}$ c.p.m. ( $\mu$ g DNA) ${ }^{-1}$ were obtained. Hybridization conditions were as described by Vargas et al. (1990).

\section{Results and Discussion}

\section{Preliminary screening for autochthonous plasmids from moderately halophilic eubacteria}

The moderate halophiles are not only important in the ecology of hypersaline environments, but also very interesting from a genetic point of view. Their ability to grow in a broad range of saline concentrations might allow the transfer of DNA between non-halophilic eubacteria and extremely halophilic aerobic archaebacteria, the so-called halobacteria. The aim of this study has been to isolate autochthonous plasmids from moderate halophiles in order to use them as basic genetic elements for development of further cloning vectors. A number of strains with a broader range of tolerance growing well in media containing $0.5-25 \%(w / v)$ total salts, belonging to the genera Halomonas, Deleya and Vibrio, were selected for these studies.

Standard procedures for the detection of plasmids (Birnboim, 1983; Kado \& Liu, 1981; Holmes \& Quigley, 1981), as well as some modifications of the alkaline lysis method as recommended for Halomonas strains by Vreeland (1984) were performed, in which cell suspensions in SDS were heated to $65^{\circ} \mathrm{C}$ during the lysis treatment. In a low proportion of preparations, thin DNA bands suggested the presence of plasmids (data not shown). When larger preparations of closed circular DNA extracted from strains in which a plasmid had

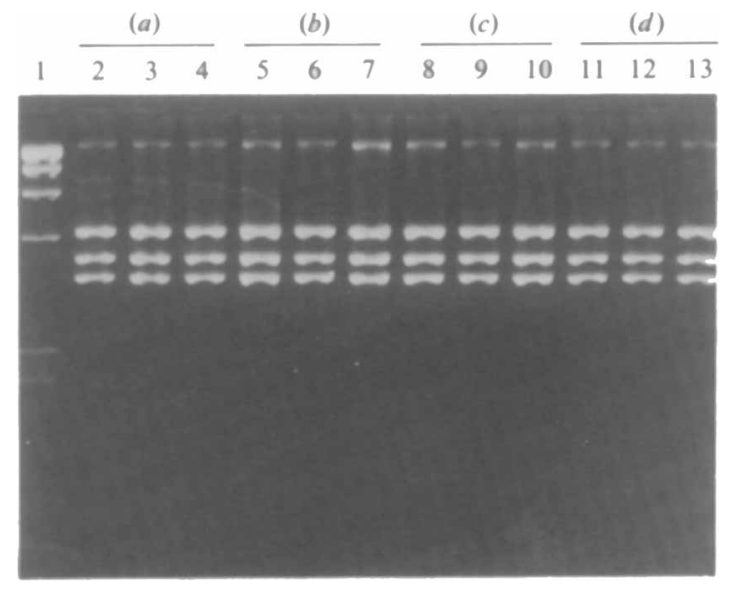

Fig. 1. HindIII-generated fragments of plasmid DNA from E. coli JM101 cells transformed with plasmid preparations from moderate halophiles. (a) Halomonas elongata; (b) Deleya halophila; (c) Halomonas halmophila; and (d) Vibrio costicola. Transformant selection was done on LB with tetracycline (lanes 2, 5, 8 and 11), kanamycin (lanes 3, 6, 9 and 12), or neomycin (lanes 4, 7,10 and 13). Lane 1, HindIII digestion of bacteriophage lambda DNA.

been observed were purified further by $\mathrm{CsCl} /$ ethidium bromide density gradient, no plasmid DNA was recovered, despite several modifications of the alkaline lysis method. These difficulties might be due to thermostable nucleases which could cause rapid breakdown of DNA following cell lysis. The production of such enzymes has been reported in several moderate halophiles (Kamekura, 1986; Onishi et al., 1983; Vreeland, 1984). Indeed, the majority of strains tested showed a remarkable DNAase activity. Therefore, standard methods seemed to be unsuitable for obtaining plasmid DNA from moderate halophiles.

\section{Screening for plasmids from moderate halophiles which codify for antibiotic resistance: isolation of pMHI}

In order to purify plasmid DNAs and to check whether plasmids carried useful genetic markers, we transformed competent $E$. coli cells with plasmid DNA from the strains investigated, and selected transformants on LB medium with a range of antibiotics. Using this approach, the only plasmids detected would be those maintained in $E$. coli cells that conferred antibiotic resistance. These are important genetic characteristics for plasmids to be used as basic elements for the construction of cloning vectors. This method has been employed elsewhere to facilitate the characterization of plasmids which can not be easily visualized (Maniatis et al., 1982; Vargas et al., 1990). With strains in which the presence of plasmids had been detected by the previous screening, a number of colonies were obtained on LB media containing kana- 


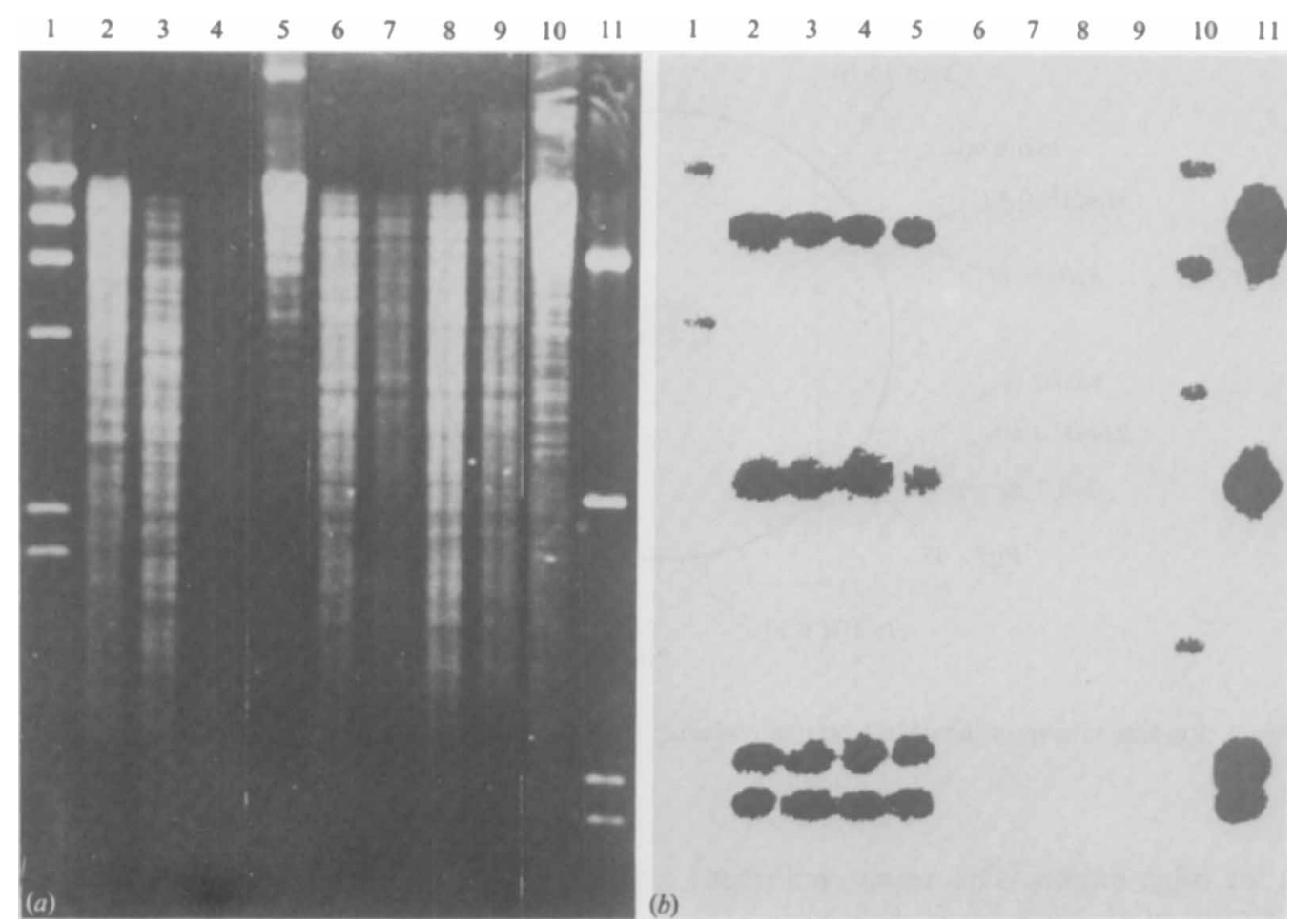

Fig. 2. (a) Agarose gel electrophoresis of PstI-generated fragments of DNA from $H$. elongata (lane 2), $D$. halophila (lane 3 ), $H$. halmophila (lane 4), V. costicola NCMB 701 (lane 5), Halobacterium salinarium (lane 6), Haloferax gibbonsii (lane 7), Haloferax volcanii (lane 8), V. costicola AV22 (lane 9), E. coli JM109 (lane 10) and pMH1 (lane 11). Lane 1, HindIII-digested lambda DNA. (b) Hybridization patterns of the above DNA samples against a EcoR1-digested pMH1 DNA probe.

mycin $(\mathrm{Km})$, neomycin $(\mathrm{Nm})$, or tetracycline $(\mathrm{Tc})$ when the donor DNA was extracted from $H$. elongata, $H$. halmophila, D. halophila, or $V$. costicola. Four sets of representative strains, each deriving from transformants with resistance to $\mathrm{Km}, \mathrm{Nm}$, or Tc and obtained with each of the four different original DNAs, were subsequently screened for their plasmid profiles after digestion with several endonucleases. In all cases, a single identical plasmid profile was detected for all the different representative strains, regardless of the parent strain from which the DNA was extracted, or the antibiotic used. The plasmid profiles after digestion with HindIII are shown in Fig. 1. The four moderate halophiles contained the same $11.5 \mathrm{~kb}$ plasmid, designated pMH1 (for moderate halophiles) and coding for resistance to kanamycin, neomycin, and tetracycline. The transformation procedures were repeated four times with the same results. To determine the maximum level of antibiotic resistance conferred, the transformed plasmidcontaining strains were grown in LB medium with increased antibiotic concentrations. The highest resistances to kanamycin, tetracycline and neomycin were $(\mu \mathrm{g} / \mathrm{ml}): 500,100$ and 50 , respectively.

Additional conjugation and transformation experi- ments were carried out in order to determine the possible transfer of pMH1 to E. coli. A spontaneous rifampicinresistant mutant of strain JM101 was used as recipient. The plasmid was transferred by both genetic transfer mechanisms, but a high frequency of transfer was found only with transformation. Therefore, pMH1 can be stably maintained and transferred into $E$. coli cells, and the multiple antibiotic resistance phenotype is associated with the presence of $\mathrm{pMH} 1$.

\section{Presence of $p H M 1$ in the genome of the parent moderately halophilic strains}

The occurrence of pMH1 was confirmed by Southern hybridization analysis. Genomic DNA from the parent strains was prepared, digested with PstI and isolated by agarose gel electrophoresis (see Methods). Total DNA from three halobacteria, another Vibrio costicola strain and $E$. coli $\mathrm{JM} 109$ were included as negative controls; pMH1 DNA also digested with PstI was added as a positive control. As shown in Fig. 2, the same pMH1 PstI hybridizing fragments were represented in digested genomic DNA from the four original strains as well as in $E$. coli, while in contrast they were absent in DNA 


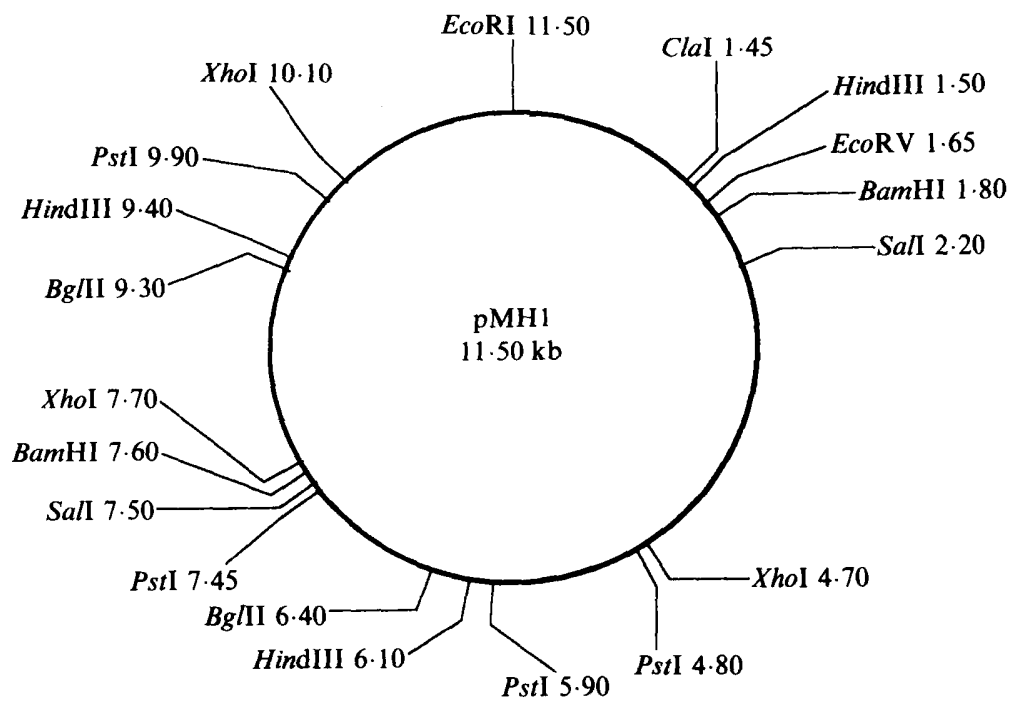

Fig. 3. Restriction map of the pMH1 plasmid, showing cleavage sites for the restriction endonucleases used.

extracted from the other strains. This result confirmed that the tested strains of $H$. elongata, $H$. halmophila, $D$. halophila and $V$. costicola harboured a homologous plasmid. The presence of homologous sequences in the total DNA of $E$. coli is not surprising, since this might explain the ease with which pMH1 can be maintained and transferred among $E$. coli cells. On the other hand, although the hybridizations were carried out under a high stringency, slight non-specific signals were detected with two of the HindIII fragments of lambda marker; this is not an unusual observation in hybridization experiments.

\section{Restriction map of pMHI}

In order to construct a pMH 1 physical map, the plasmid from $E$. coli cells, which had been previously transformed with plasmid DNA derived from $H$. elongata, was prepared using a large-scale alkaline lysis method (Morelle, 1989), purified by $\mathrm{CsCl} /$ ethidium bromide density gradients, and digested with nine restriction endonucleases (as well as with their double and triple combinations). The enzymes used were: $B a m H I, B g l I I$, ClaI, EcoRI, EcoRV, HindIII, PstI, SalI, and XhoI, respectively. The map (Fig. 3) shows that of the restriction enzymes tested, only EcoRI, EcoRV, and ClaI cleaved pMH1 once. Moreover, pMH1 also contained cleavage sites for a number of other commonly employed site-specific endonucleases. These restriction sites are: SalI, 2; BamHI, 2; BglII, 2; HindIII, 3; XhoI, 3; and PstI, 4.

We conclude that pMH1 is a good candidate for a cloning vector for moderately halophilic bacteria, since this plasmid satisfies the following conditions: (i) it is stably maintained and transferred in E. coli cells; (ii) it is relatively small; (iii) it possesses a selectable marker; (iv) it contains unique restriction enzyme sites for cloning purposes (Old \& Primrose, 1989).

The common occurrence of $\mathrm{pMH} 1$ in the four moderately halophilic strains may reflect the very close relationship within the family Halomonadaceae (Franzmann et al., 1988) of three strains. Although V. costicola was first isolated from cured meats (Smith, 1938), we have found that this species is one of the predominant micro-organisms which inhabit hypersaline waters (Ventosa et al., 1982; García et al., 1987; Márquez et al., 1987) or soils (Quesada et al., 1982) together with members of the Halomonadaceae. Since these moderate halophiles can be present in the same ecological habitats, pMH1 may codify functions which are common for these microorganisms. This resembles the situation of their halophilic counterparts, the halobacteria, in which the general occurrence of cryptic plasmids of different sizes have been reported (Gutiérrez et al., 1986). The presence of antibiotic resistance markers in $\mathrm{pMH1}$ is not surprising, since very recently a high incidence of antibiotic resistance in bacteria which inhabit environments virtually free from anthropogenic influence has been found (Magee \& Quinn, 1991). Experiments to determine some possible functions of $\mathrm{pMH} 1$ are in progress.

This investigation was supported by grants from the Direccion General de Investigación Científica y Técnica (PB87-0945) and from the Junta de Andalucía. 


\section{References}

Ausubel, F. M., Brent, R., Kingston, R. E., Moore, D. D., Seidman, J. G., SMith, J. A. \& STRUHL, K. (1989). Current Protocols in Molecular Biology. Greene Publishing Associates, NY: John Wiley and Sons.

BiRNBoIM, H. C. (1983). A rapid alkaline extraction method for the isolation of plasmid DNA. Methods in Enzymology 100, 243255.

Franzmann, P. D. Wehmeyer, U. \& Stackebrandt, E. (1988). Halomonadaceae fam. nov., a new family of the class Proteobacteria to accommodate the genera Halomonas and Deleya. Systematic and Applied Microbiology 11, 16-19.

Garcia, M. T., Ventosa, A., Ruiz-Berraquero, F. \& Kokur, M. (1987). Taxonomic study and amended description of Vibrio costicola. International Journal of Systematic Bacteriology 37, 251256.

Gutiérrez, M. C., Ventosa, A., Nieto, J. J. \& Ruiz-Berraquero, F. (1986). Occurrence of megaplasmids in halobacteria. Journal of Applied Bacteriology 61, 67-71.

Holmes, D. S. \& QUIGLEY, M. (1981). A rapid boiling method for the preparation of bacterial plasmids. Analytical Biochemistry 114, 193197.

KADO, C. I. \& LIU, S. T. (1981). Rapid procedure for detection and isolation of large and small plasmids. Journal of Bacteriology 145, 1365-1373.

KAMEKURA, M. (1986). Production and function of enzymes of eubacterial halophiles. FEMS Microbiology Reviews 39, 145-150.

KUSHNER, D. J. (1978). Life in high salt and solute concentrations: halophilic bacteria. In Microbial Life in Extreme Environments, pp. 317-368. Edited by D. J. Kushner. London: Academic Press.

Kushner, D. J. \& Kamekura, M. (1988). Physiology of halophilic eubacteria. In Halophilic Bacteria, vol. I, pp. 109-140. Edited by F. Rodriguez-Valera. Boca Raton, Florida: CRC Press

MAgeE, A. M. \& QuinN, J. P. (1991). Antibiotic resistance in the bacteria of a remote upland river catchment. Letters in Applied Microbiology 13, 145-149.

Maniatis, T., Fritsch, E. \& SAMBrooK, J. (1982). Molecular Cloning : a Laboratory Manual. Cold Spring Harbor, NY: Cold Spring Harbor Laboratory.

Marquez, M. C., Ventosa, A. \& Ruiz-Berraquero, F. (1987). A taxonomic study of heterotrophic halophilic and non-halophilic bacteria from a solar saltern. Journal of General Microbiology 133, 4556.

MORELLE, G. (1989). A plasmid extraction procedure on a miniprep scale. BRL Focus 11, 7-8.
Nieto, J. J., Fernandez-Castillo, R., Marquez, M. C., Ventosa, A \& RUIZ-BerRaQuero, F. (1989). A survey of metal tolerance in moderately halophilic eubacteria. Applied and Environmental Microbiology 55, 2385-2390.

Old, R. W. \& Primrose, S. B. (1989). Principles of Gene Manipulation. An Introduction to Genetic Engineering, 4th edn. Oxford: Blackwell Scientific Publications.

Onishi, H., Mori, T., Takeuchi, S., Tani, K., Kobayashi, T. \& KAMEKURA, M. (1983). Halophilic nuclease of a moderately halophilic Bacillus sp: production, purification, and characterization. Applied and Environmental Microbiology 45, 24-30.

Quesada, E., Ventosa, A., Rodriguez-Valera, F. \& RamosCormenzana, A. (1982). Types and properties of some bacteria isolated from hypersaline soils. Journal of Applied Bacteriology 53, 155-161.

RODRIGUEZ-VALERA, F. (1986). The ecology and taxonomy of aerobic chemoorganotrophic halophilic eubacteria. FEMS Microbiology Reviews 39, 17-22.

Rodriguez-Valera, F., Ventosa, A., Juez, G. \& ImHoff, J. (1985). Variation of environmental features and microbial populations with salt concentrations in a multipond saltern. Microbial Ecology 11, 107115.

SMITH, F. B. (1938). An investigation on a taint in rib bones of bacon. The determination of halophilic vibrios (n. spp.). Proceedings of the Royal Society of Queensland 49, 29-53.

SouTHERN, E. M. (1975). Detection of specific sequences among DNA fragments separated by gel electrophoresis. Journal of Molecular Biology 98, 503-517.

Vargas, C., Martinez, L. J., Megias, M. \& Quinto, C. (1990). Identification and cloning of nodulation genes and host specifity determinants of the broad host-range Rhizobium leguminosarum biovar phaseoli strain CIAT899. Molecular Microbiology 4, 18991910.

Ventosa, A. (1988). Taxonomy of moderately halophilic heterotrophic eubacteria. In Halophilic Bacteria, vol. I, pp. 71-84. Edited by F. Rodriguez-Valera. Boca Raton, Florida: CRC Press.

Ventosa, A., Quesada, E., Rodriguez-Valera, F., Ruiz-BerraQUERo, F. \& RAMOS-CORMENZANA, A. (1982). Numerical taxonomy of moderately halophilic Gram-negative rods. Journal of General Microbiology 128, 1959-1968.

VREELAND, R. H. (1984). Genus Halomonas. In Bergey's Manual of Systematic Bacteriology, vol. 1, pp. 340-343. Edited by N. R. Krieg \& J. G. Holt. Baltimore: Williams \& Wilkins.

Yanisch-Perron, C., Vieira, J. \& Messing, J. (1985). Improved M13 phage cloning vectors and host strains: nucleotide sequences of the M13mp18 and pUC19 vectors. Gene 33, 103-119. 